\title{
Occurrence and distribution of Diaphorina citri (Hemiptera: Liviidae) and Tamarixia radiata (Hymenoptera: Eulophidae) in Pará state, Brazil
}

\author{
Ocorrência e distribuição de Diaphorina citri (Hemiptera: Liviidae) \\ e Tamarixia radiata (Hymenoptera: Eulophidae) no estado do Pará
}

\author{
Aloyséia Cristina da Silva Noronha1* (D), Dimison Garcia Blanco² (D), Alessanda Keiko Nakasone

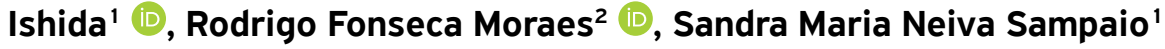

| | | | | | | | | | | | | | | | | | | | | | | | | | | | | | | | | | | | | | | | | | | | | | | | | | | | | | | | | | | | | | | | | | | | | | | | | | | | | | | | | | | | | | | | | | | | | | | | | | | | | | | | | | | | | | | | | | | | | | | | | | | | | | | | | | | | | | | | | | | | | | | | | | | | | | | | | | | | | | | | | | | | | | | | | | | | | | | | | | | | | | | | | | | | | | | | | | | | | |

\begin{abstract}
This study presents and discusses the results of a survey for the presence of Diaphorina citri Kuwayama and its natural enemies in Citrus spp. citrus and Murraya sp. myrtle plants in Pará State, Brazil. From 2013 to 2017, observations were made in five mesoregions of the State, and where D. citri was present, branches were examined to quantify eggs, nymphs and mummies with parasitoid emergence holes and to obtain parasitoids. D. citri adults were used to detected the bacterium through nested polymerase chain reaction (NESTED-PCR). Psyllids were found in citrus and myrtle plants. A total of 583 parasitoid specimens of Tamarixia radiata (Waterston) were obtained. The bacterial detection test was negative for Candidatus Liberibacter spp. Psyllids and parasitoids were present in the Lower Amazon, Metropolitan area, Northeastern Pará, Southeastern Pará and Southwestern Pará mesoregions. The presence of $D$. citri in citrus, with was previously absent in this host, alters the risk situation for Huanglongbing (HLB) in the State. These results will aid in developing preventive or containment measures through phytosanitary protection.
\end{abstract}

KEYWORDS: Huanglongbing; citrus; Murraya sp.; biological control.
RESUMO: No presente estudo, são apresentados e discutidos os resultados de levantamento para a presença de Diaphorina citri Kuwayama e inimigos naturais em plantas de citros Citrus spp. e murta Murraya sp. no estado do Pará. No período de 2013 a 2017 foram realizadas observaçóes em cinco mesorregióes do estado. Na presença de D. citri, ramos foram coletados com a quantificaçáo de ovos, ninfas, múmias com orifício de emergência de parasitoide e obtençáo de parasitoides. Adultos de D. citri foram analisados para a detecçáo da bactéria por meio de nested polymerase chain reaction (NESTED-PCR). O psilídeo foi constatado em citros e murta. Foram obtidos 583 exemplares do parasitoide Tamarixia radiata (Waterston). O teste de detecção da bactéria foi negativo, indicando ausência de Candidatus Liberibacter spp. O psilídeo e o parasitoide estão presentes nas mesorregióes do Baixo Amazonas, Metropolitana, Nordeste Paraense, Sudeste Paraense e Sudoeste Paraense. A presença de $D$. citri em citros, até então ausente nesse hospedeiro, altera a situação de risco do Huanglongbing (HLB) para o Estado. Esses resultados auxiliarão na formulaçáo de medidas preventivas ou de contenção pela defesa fitossanitária.

PALAVRAS-CHAVE: Huanglongbing; citros; Murraya sp.; controle biológico. 
Huanglongbing (HLB) is considered one of the most serious diseases in citrus fruit (Citrus spp.) and is the main phytosanitary problem in countries where the disease occurs (BOVÉ, 2006). The first report of HLB in Brazil occurred in 2004 in the Araraquara municipality, Sáo Paulo state, and the disease is currently present in Paraná and Minas Gerais states (COLETTA-FILHO et al., 2004; CASTRO et al., 2010). HLB is associated with the Candidatus Liberibacter spp. bacteria, which is restricted to plant phloem vessels (MACHADO et al., 2010). In the Americas, the $C a$. L. asiaticus bacterium is the most widespread species and is present in all countries where the disease has been reported (YAMAMOTO et al., 2014).

The Asian citrus psyllid Diaphorina citri Kuwayama (Hemiptera: Liviidae) is important because it is a vector of the bacterium associated with HLB (MACHADO et al., 2010). D. citri is present in nearly all citrus-producing regions of Brazil, and the ornamental myrtle plant, Murraya paniculata (Rutaceae), is its preferred host for development (NAVA et al., 2007). Female D. citri place egg clusters at the shoot tips; thus, shoot availability is a limiting factor in oviposition (PARRA et al., 2010). To control insect vectors, synthetic insecticides are used to eliminate infective individuals. Another alternative is to use biological control (parasitoids, predators and pathogens). Among the parasitoids, Tamarixia radiata (Waterston) (Hymenoptera: Eulophidae) has been successfully used in countries where HLB occurs (PARRA et al., 2010).

In Brazil, the highest population density of $D$. citri in commercial citrus orchards and myrtle was recorded in Bahia. The insect was not found in citrus orchards in the states of Amazonas and Pará, which are nonendemic for HLB (NASCIMENTO et al., 2016).

Pará state is the largest citrus producer in the north region, with two citrus production centers in the microregions of Guamá (orange) and Santarém (Tahiti); in 2017, it accounted for $1.97 \%$ of national production, representing $81 \%$ of regional production (IBGE, 2017). In regions where HLB remains undetected, exclusion and eradication measures are essential to avoid its introduction and to enable its early eradication (LARANJEIRA et al., 2011).

This study presents and discusses the results of a survey conducted to determine the presence of $D$. citri and its natural enemies (parasitoids) on citrus and myrtle plants to obtain information on the HLB vector's distribution range and on parasitoids in Pará state.

Nonconsecutive observations were made from April 2013 to September 2017 in five mesoregions of the state: The Lower Amazon, the Metropolitan area, Northeast Pará, Southeast Pará and Southwestern Pará. D. citri presence was evaluated in new plant shoots on farms and in public places (squares, sidewalks), gardens and roadsides. When adult insects were present, eggs and/or nymphs and branches (up to $15 \mathrm{~cm}$ ) were collected and packed in labelled plastic bags for transport to the laboratory. The number of branches per plant varied depending on the plant's vegetative development (height, flowering, fruiting, new shoots). Adult specimens, when detected, were collected directly in plastic tubes containing $70 \%$ alcohol, with a sample representing each sampling/observation point. The number of observation points per mesoregion varied (8 to 97), and all were georeferenced, with each point corresponding to one or more citrus and/or myrtle plants (sampling up to 30 plants/point).

In the laboratory, the numbers of eggs, yellow or darkened nymphs with parasitoid development (NYD), and D. citri mummies with characteristic parasitoid emergence holes $(\mathrm{NH})$ were quantified. To obtain the parasitoids, branches with nymphs were individually placed in glass tubes sealed with polyvinylchloride film and observed daily for up to 15 days. The D. citri adults and emerged parasitoids were collected and preserved in $70 \%$ alcohol. The parasitism rate was obtained using the ratio of the number of parasitized nymphs to total nymphs (parasitized and nonparasitized). Adult D. citri specimens collected at 27 observation points and stored in $96^{\circ} \mathrm{C}$ alcohol were analyzed to screen for the bacterium using nested polymerase chain reaction (NESTED-PCR).

Observations were made in 16 microregions in the state's 5 mesoregions (Fig. 1). Regarding D. citri presence, 48 points with citrus plants, 146 with myrtle plants and 2 with both citrus and myrtle were observed, totaling 196 evaluation sites (sampling points) in 46 municipalities. D. citri was found in myrtle plants in 32 municipalities at 95 sampling points. D. citri was present in only one of the two sites containing both citrus and myrtle plants, a fruit (including citrus) and ornamental seedling nursery, but the insect was only present in myrtle seedlings. Some points were visited more than once, and the insect's presence was not observed on all visits. Of the 146 observation points containing myrtle, 36 were visited two or three times, and D. citri was absent in nine of them.

In the myrtle, 881 adult $D$. citri specimens were collected, considering both the specimens collected in the field and those obtained in the laboratory from nymphs present on the branches. Of the 1,415 myrtle branches collected, 7,072 eggs and 5,635 nymphs were counted, averaging 5.0 eggs and 3.98 nymphs per branch (Table 1). In the citrus plants, D. citri was detected in 2017 in an urban area at two sampling points in the Castanhal (orange orchard) and Peixe-Boi (lemon plant) municipalities (Table 1). Although darkened and apparently parasitized nymphs were found on the branches from Castanhal, no parasitoids were found.

Of the 6,438 nymphs observed in myrtle, $12.47 \%$ had characteristic parasitoid emergence holes. A total of 583 parasitoids were identified as $T$. radiata. Confirmed parasitism 
or signs of parasitism (contained a hole or were darkened in color without parasitoid emergence) by $D$. citri nymphs were observed in 23 municipalities in all five mesoregions.

To detect the bacteria, adult $D$. citri specimens collected from myrtle in Belém, Castanhal, Capitão Poço, Igarapé-Açu, Irituia, Tomé-Açu, Breu Branco, Tucuruí and Santarém municipalities were analyzed. The analyzed samples were negative for the bacteria, indicating the absence of Candidatus Liberibacter spp.

D. citri was found in $94 \%$ of the microregions visited, although some microregions, such as Conceição do Araguaia, Marabá and Redenção (IBGE, 2017), were not listed as
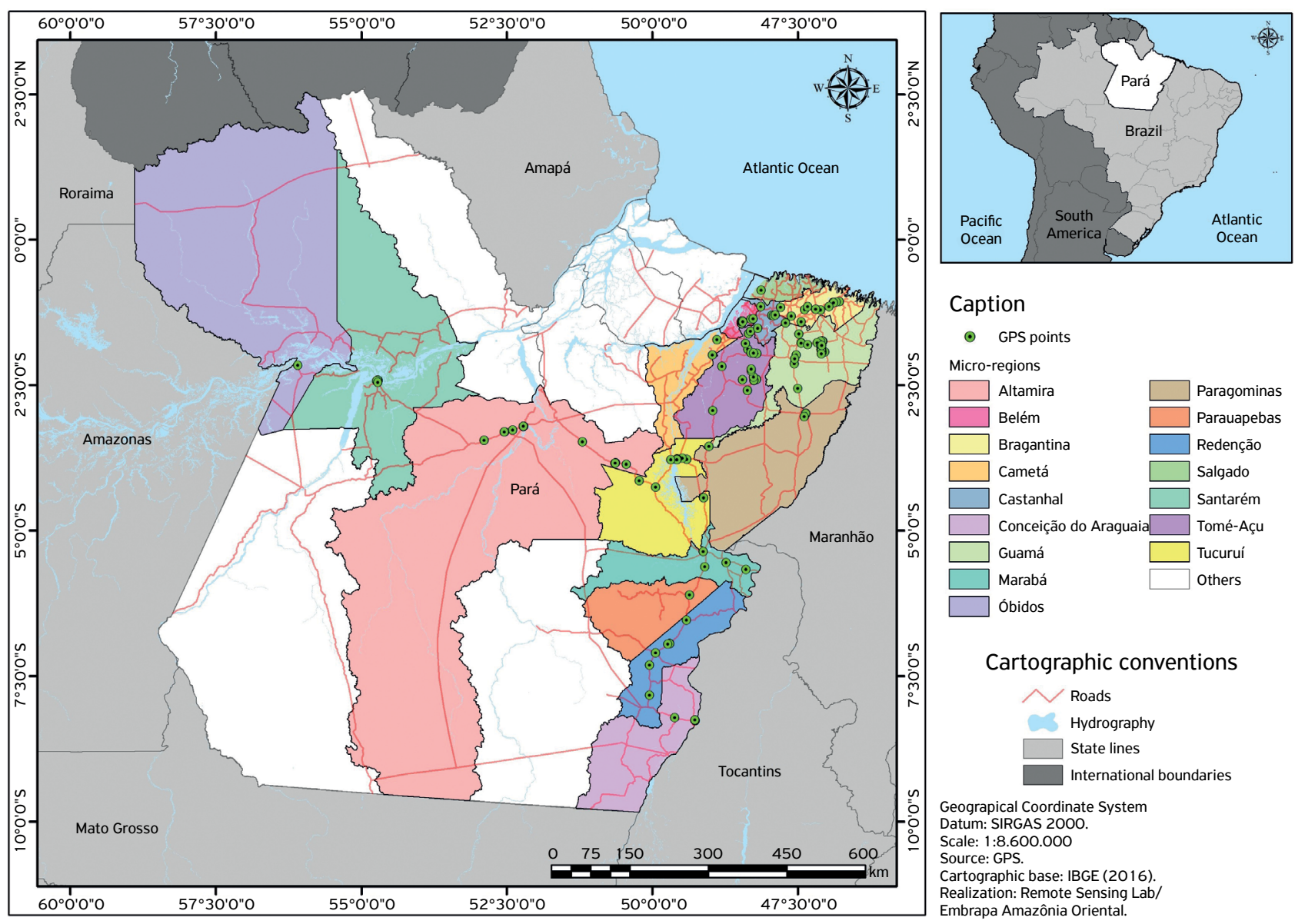

Cartographic conventions

Roads
Hydrography
State lines
International boundaries
S.600.000
pPS.
onic base: IBGE (2016).
Amazônia Oriental.

Figure 1. Diaphorina citri observation and/or sampling points in citrus (Citrus spp.) and myrtle (Murraya sp.) plants in microregions in Pará state.

Table 1. Number of Diaphorina citri eggs and nymphs in myrtle (Murraya sp.) and citrus (Citrus spp.) branches and of the parasitoid

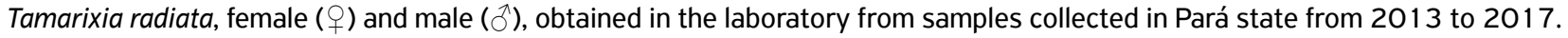

\begin{tabular}{|c|c|c|c|c|c|c|c|c|}
\hline \multirow{3}{*}{ Year } & \multirow{3}{*}{ Host } & \multicolumn{7}{|c|}{ Number } \\
\hline & & \multirow{2}{*}{ Branches } & \multirow{2}{*}{ Eggs } & \multicolumn{2}{|c|}{ Nymphs* } & \multicolumn{3}{|c|}{ T. radiata } \\
\hline & & & & NYD & NH & q & $\hat{\sigma}$ & Total \\
\hline 2013 & Myrtle & 94 & 551 & 226 & 122 & 27 & 33 & 60 \\
\hline 2014 & Myrtle & 309 & 1,758 & 1,070 & 39 & 101 & 68 & 169 \\
\hline 2015 & Myrtle & 598 & 2,886 & 2,270 & 466 & 163 & 120 & 283 \\
\hline 2016 & Myrtle & 382 & 1,906 & 1,831 & 112 & 23 & 17 & 40 \\
\hline \multirow[t]{2}{*}{2017} & Myrtle & 32 & 0 & 238 & 64 & 18 & 13 & 31 \\
\hline & Citrus & 31 & 80 & 116 & 0 & 0 & 0 & 0 \\
\hline Total & & 1,446 & 7,152 & 5,751 & 803 & 332 & 251 & 583 \\
\hline
\end{tabular}

*NYD: yellowish or darkened color; $\mathrm{NH}$ : D. citri mummy with parasitoid emergence hole. 
citrus-producing regions. Therefore, psyllids were present in five mesoregions of the state. D. citri was detected in citrus in an urban area; however, it was unobserved during two years of biweekly monitoring in rural citrus-producing areas in Capitão Poço and Castanhal (NORONHA et al., 2014). In the Recôncavo region of Bahia, population density of D. citri in myrtle was approximately 1.4 times higher than that in the citrus host (NASCIMENTO et al., 2016).

Tamarixia radiata and signs of parasitoid presence (nymphs with parasitoid emergence holes or darkened without parasitoid emergence) were found in $50 \%$ of the municipalities visited, corresponding to $72 \%$ of the municipalities where D. citri was present. The parasitism rate in myrtle plants was $11 \%$, considering that only darkened nymphs collected from plants without insecticide application were quantified. PAIVA; PARRA (2012) found a mean parasitism rate of $12 \%$ by T. radiata in D. citri nymphs, primarily 4 th and 5 th instar, in citrus plants subjected to regular insecticide applications. T. radiata presence in citrus-producing and nonproducing regions is an alternative for biological control to manage $D$. citri.

Although a low $D$. citri population density was observed in myrtle in Pará, the insect's presence in citrus, which was previously absent in this host (NASCIMENTO et al., 2016), changes the risk situation for HLB in the state. Several quarantine and exotic pests have entered Brazil through the Amazon. MORAIS et al. (2016) cite several reasons for the region's vulnerability to quarantine pests: The large border, the intense flow of people, the transit of plant material and the poor performance of neighboring countries in phytosanitary protection. HLB is present in Colombia, Panama and Trinidad and Tobago (ICA, 2017). The risk for citrus farming in the Amazon is imminent, given the presence of $D$. citri in lemon trees and in myrtle in the Boa Vista municipality, in Roraima state (MARSARO JÚNIOR et al., 2014), which has terrestrial access routes to Guyana and Venezuela.

The present study's results regarding $D$. citri and $T$. radiata distribution in the state will allow the necessary phytosanitary protection measures to be defined (contingency plan), with preventive or containment actions before HLB is possibly disseminated to other regions of Brazil or before it enters through the Amazon region.

\section{ACKNOWLEDGMENTS}

The authors thank Dr. Dalva Luiz de Queiroz (Embrapa Florestas) and Dr. Valmir Antônio Costa (Instituto Biológico), respectively, for identifying the psyllid and the parasitoid. This study was funded by EMBRAPA through the projects PSYBR (02.12.01.028.00.00) and HLB BioControl (02.13.03.004.00.00).

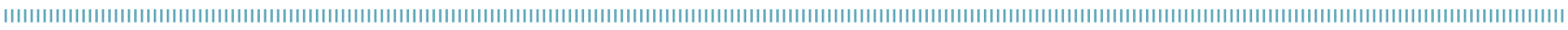
REFERENCES

BOVÉ, J.M. Huanglongbing: a destructive, newly-emerging, century-old disease of citrus. Journal of Plant Pathology, Bari, v.88, n. 1, p.7-37, 2006.

CASTRO, M.E.A.; BEZERRA, A.R.; LEITE, W.A.; MUNDI FILHO, W.; NOGUEIRA, N.D. Situação e ações do Estado de Minas Gerais frente ao huanglongbing. Citrus Research $\curvearrowright$ Tecnology, Cordeirópolis, v.31, n.2, p. 163-168, 2010.

COLETTA-FILHO, H.D.; TARGON, M.L.P.N.; TAKITA, M.A.; DE NEGRI, J.D.; POMPEU JUNIOR, J.; MACHADO, M.A.; AMARAL, A.M.; MULLER, G.W. First report of the causal agent of Huanglongbing ("Candidatus Liberibacter asiaticus") in Brazil. Plant Disease, Saint Paul, v.88, n.2, p.1382, 2004.

INSTITUTO COLOMBIANO AGROPECUARIO (ICA). Sistema de Alerta Fitossanitário, 2017. Available from: <https://www.ica. gov.co/Alertas-Fitossanitarias/Noticias.aspx>. Accessed on: Nov. 272017.

INSTITUTO BRASILEIRO DE GEOGRAFIA E ESTATÍSTICA (IBGE). Sistema IBGE de Recuperação Automática-SIDRA, 2017. Available from: <https://sidra.ibge.gov.br/tabela/1613\#resultado>. Accessed on: Nov. 142018.
LARANJEIRA, F.F.; SILVA, C.X.B.; ANDRADE, E.C.; NASCIMENTO, A.S.; ALMEIDA, D.O.; MAGALHÃES, E.; NUNES, C.C.S.; MOTTA, R.S.; BOMFIM, R.C.L.; ALMEIDA, M. A.C.C. Mapeamento de hospedeiros suscetíveis ao HUANGLONGBING dos citros no Recôncavo Baiano. Cruz das Almas: Embrapa Mandioca e Fruticultura, 2011.20p. (Boletim de Pesquisa e Desenvolvimento/Embrapa Mandioca e Fruticultura, 55). https://doi.org/10.13140/2.1.4875.8087

MACHADO, N.A.; LOCALI-FABRIS, E.C.; COLETTA FILHO, H.D. Candidatus Liberibacter spp., agentes do huanglongbing dos citros. Citrus Research \& Tecnology, Cordeirópolis, v.31, n.1, p.25-35, 2010.

MARSARO JÚNIOR, A.L.; GUIDOLIN, A.S.; CÔNSOLI, F.L.; FREITASASTÚA, J. Primeiro registro de Diaphorina citri Kuwayama, 1908 (Hemiptera: Liviidae) para o estado de Roraima, Brasil. Revista de Agricultura, Piracicaba, v.89, n.3, p.183-186, 2014.

MORAIS, E.G.F.; JESUS-BARROS, C.R.; ADAIME, R.; LIMA, A.L.; NAVIA, D. Pragas de expressão quarentenária na Amazônia. In: SILVA, N.M.; ADAIME, R.; ZUCCHI, R.A. (Eds.). Pragas Agrícolas e Florestais na Amazônia. Brasília: Embrapa, 2016. p. 521-559. 
NASCIMENTO, A.S.; SILVA, S.X.B.; LARANJEIRA, F.F.; NORONHA, A.C.S.; NAVA, D.E.; GARCIA, M.V.B.; ALENCAR, J.A. Densidade populacional de Diaphorina citri (Hemiptera: Liviidae), vetor do huanglongbing (ex-greening), em quatro regiões indenes no Brasil. In: CINTRA, F.L.C.; FONTES, H.R.; BARROS, I.; TEODORO, A.V. (Eds.). SEMINÁRIO DE INTENSIFICAÇÃO ECOLÓGICA DA FRUTICULTURA, 4., Brasília, 2016. Anais... Brasília: Embrapa, 2016. p.128-134.

NAVA, D.E.; TORRES, M.L.G.; RODRIGUES, M.D.L.; BENTO, J.M.S.; PARRA, J.R.P. Biology of Diaphorina citri (Hem., Psyllidae) on different hosts and different temperatures. Journal of Applied Entomology, Berlin, v.131, n.9-10, p.709-715, 2007. https:// doi.org/10.1111/j.1439-0418.2007.01230.x

NORONHA, A.C.S.; ISHIDA, A.K.N.; MENDONÇA, C.L.G.; CARVALHO, K.B.A.; FERREIRA, C.T.; NASCIMENTO, A.S. Monitoramento de Diaphorina citri (Hemiptera: Liviidae) em pomares de citros no estado do Pará. In: CONFERÊNCIA NACIONAL DE DEFESA
AGROPECUÁRIA, 4., Belém, PA, 2013. Anais... Defesa agropecuária e sustentabilidade. Belém, PA: SBDA, 2014. p.194-195.

PAIVA, P.E.B.; PARRA, J.R.P. Natural parasitism of Diaphorina citri Kuwayama (Hemiptera, Psyllidae) nymphs by Tamarixia radiata Waterston (Hymenoptera, Eulophidae) in São Paulo orange groves. Revista Brasileira de Entomologia, São Paulo, v.56, n.4, p.499-503, 2012. http://dx.doi.org/10.1590/ S0085-56262012000400016

PARRA, J.R.P.; LOPES, J.R.S.; GÓMEZ-TORRES, M.L.; NAVA, D.E.; PAIVA, P.E.B. Bioecologia do vetor Diaphorina citri e transmissão de bactérias associadas ao Huanglongbing. Citrus Research $\odot$ Tecnology, Cordeirópolis, v.31, n.1, p.37-51, 2010. http://dx.doi. org/10.5935/2236-3122.20100004

YAMAMOTO, P.T.; ALVES, G.R.; BELOTI, V.H. Manejo e controle do huanglongbing (HLB) dos cítricos. Investigación Agraria, San Lorenzo, v. 16, n.2, p.69-82, 2014. 